акула. Слова-помічники: кульки - повітряні, різнокольорові, легкі; потяг - пасажсирський, яскравий, веселий. Завдання: скласти казку про акулу, використовуючи знайдені словапомічники.

«Жила собі в морських глибинах тітонька акула. Вона була дуже доброю $і$ знала всіх малят в океані. I ось настав день ї̈ народження. Акула вдягла гарненьку шкіру, сіла в яскравий пасажсирський потяг, який піднімав їй настрій. Вона так швидко їхала, щуо ї̈ плавник аж винирював із глибин. Тітонька акула приїхала до своїх друзів, які вітали ї зі святом. Вона пригостила їх смачним морозивом з водоростей, а вони в свою чергу заспівали веселих пісень і подарували їй легкі різнокольорові кульки».

Тема «Звук [y], позначення його буквами Уу». Використаємо прийом «Біном фантазії». Пропонуємо учням придумати фантастичну історію, у якій всі слова починатимуться на «у». Проте спочатку першокласники мають пригадати і дібрати такі слова 3 початковим [y], запам'ятати їх, щоб згодом пов'язати за змістом і використати у власному зв'язному висловлюванні.

Отже, ТРВЗ-технологія має багато позитивних сторін: у дітей збагачується коло уявлень, зростає словниковий запас, розвиваються творчі здібності. ТРВ3 допомагає формувати логічне мислення, сприяє подоланню сором'язливості, замкнутості, остраху; маленька людина вчиться відстоювати свою точку зору, а потрапляючи у важкі ситуації, самостійно знаходити оригінальні рішення; сприяє розвитку наочно-образного, причинового, евристичного мислення, пам'яті, уяви, впливає на інші психічні процеси. Окрім того, використання засобів ТРВ3 на уроках навчання грамоти дозволяє формувати комунікативну компетенцію, вміння бачити, аналізувати і розв'язувати навчальні та життєві проблеми самостійно.

\title{
Література
}

1. Введение в ТРИЗ. Основные понятия и подходы: [Электронный ресурс]. - Режим доступа: http://www.triz-chance.ru/e-books.html. 2. Демчук Л. В. Виховання творчої особистості / Л. В. Демчук // Психологічна газета. - 2007. - № 16. - С. 22-31. 3. Рибалка В. В. Поняття про творчість, творчу особистість та особистісний підхід до вивчення і розвитку творчого потенціалу молоді / В. В. Рибалка // Психологія розвитку творчої особистості. - К., 1995. - С. 5-24. 4. Сухомлинский В. А. Сердце отдаю детям / В. А. Сухомлинский. - 2-е изд. - К. : Рад. школа, 1972. - 244 с. 5. Телячук В. П. Сходинками творчості. Методика ТРВ3 у початковій школі / В. П. Телячук, О. В. Лесіна - К., Основа, 2007. - 112 с.

\section{ФОРМУВАННЯ ЧУТТЕВОЇ КУЛЬТУРИ УЧНІВ ОСНОВНОЇ ШКОЛИ У ПРОЦЕСІ ВИВЧЕННЯ ХУДОЖНЬОЇ ЛІТЕРАТУРИ}

Паламар С. П. Формування чуттєвої культури учнів основної школи у процесі вивчення художньої літератури.

У статті окреслено чинники, що впливають на формування та збагачення чуттєвої культури учнів основної школи; проаналізовано значення у цьому процесі вивчення художньої літератури. Доведено взаємозв'язок сформованості чуттєвої культури учнів основної школи з рівнем розвитку художнього виховання. Уміння здіснювати літературний аналіз художнього тексту віднесено до структури читацької компетентності учнів основної школи.

Ключові слова: чуттєва культура, учні основної школи, вивчення художньої літератури, читацька компетентність.

Паламар С. П. Формирование чувственной культуры учащихся основной школы в процес се изучения художественной литературы. 
В статье очерчены факторы, которые влияют на формирование и обогащение чувственной культуры учеников основной школы; проанализировано значение в этом процессе изучения художественной литературы. Доказана взаимосвязь сформированности чувственной культуры учеников основной школы с уровнем развития художественного воспитания. Умение анализировать литературное произведение отнесено к структуре читательской компетентности учеников основной школы.

Ключевые слова: чувственная культура, ученики основной школы, изучение художественной литературы, читательская компетентность.

Palamar S. P. Formation of sensual culture of basic school students in the process of study of literature.

The paper outlines the factors that influence the formation and enrichment of sensate culture elementary school students; analyzed in this process of studying literature. Proved the relationship of formation sensual culture elementary school students with the level of art education. The ability to analyze a literary work attributed to the structure of the reading competency of basic school pupils.

Key words: sensate culture, primary school students, the study of literature, reading competence.

В епоху інформатизації інноваційні технології, що мають місце в сучасній освітній системі, на першому плані постає насамперед особистість, яка має власну позицію; здатна обгрунтувати й довести ланцюжок міркувань із певної галузі знань; володіє соціокультурними знаннями i творчо їх перероблює відповідно до мінливих умов соціальної діяйсності.

Визначальними для повного розкриття окресленого питання є погляди на чуттєвість людини як iii сутнісну характеристику, викладені у розвідках Д. Берклі, I. Канта, Р. Декарта, Ж.-Ж. Руссо; ідеї Г. Сковороди, П. Юркевича, М. Бердяєва, А. Лосєва, П. Сорокіна, А. Канарського.

Проблема чуттєвої культури як компонента духовної культури особистості знайшла відображення в роботах таких науковців, як В. Андрущенко, І. Зязюн, С. Іконнікова, Н. Киященко, М. Реріх, Л. Рувінський, О. Рудницька, В. Фєдотова, Г. Шевченко та інші. У розвідках науковців культура почуттів розглядається як ціннісно-духовна властивість особистості, що дозволяє виявляти їі світосприймання, ставлення до світу, спонукає до творчої діяльності та соціокультурної поведінки.

Психологічні аспекти культури почуттів послідовно відображено в роботах Л. Божович, Л. Виготського, Б. Додонова, К. Ізарда, Я. Рейковського та інших. У роботах досдіників здійснено глибокій аналіз емоційних станів людини, наведено змістовні характеристики емоцій і почуттів, розкрито взаємозв'язок емоцій і потреб.

У педагогічному аспекті культура почуттів та їі виховання перебували в полі посиленої уваги Д. Локка, Я. Козельського, В. Кан-Калика, О. Макаренка, . Неменського, В. Сухомлинського, К. Ушинського. Б. Юсова та інших.

Науковці Т. Антоненко, В. Бачинін, Н. Крилова, О. Лук, Л. Коваль, Л. Сбітнєва, І. Сілютіна, Л. Соколова, В. Толстих, П. Якобсон та інші зосередили свою увагу на пошуках засобів і шляхів формування чуттєвої культури школярів та підлітків.

Перераховані шляхи досліження питання формування чуттєвої культури людини складають солідний методичний масив, що дозволяє розробити питання формування чуттєвої культури учнів основної школи у процесі вивчення художньої літератури.

Mema cmammi - окреслити чинники, що впливають на формування та збагачення чуттєвої культури учнів основної школи і проаналізувати значення у цьому процесі вивчення художньої літератури.

3 огляду на це вітчизняні реалії вимагають формування особистості нового соціокультурного типу:

1) гуманної, що усвідомлює високу цінність людського життя та розуміє самоцінність власного внутрішнього світу; має інтеріоризовані гуманістичні цінності й ідеали;

2) духовно спрямованої, зі сформованими потребами в пізнанні довкілля, самопізнанні, у спілкуванні з мистецтвом; 
3) творчої, яка має розвинений інтелект; володіє почуттям нового і здатна до активного життя і творчості;

4) прагматичної, яка володіє новітніми технологіями, набула вмінь, необхідних для реалізації предметних знань у новій економічній і соціокультурній ситуації;

5) культурологічно грамотної (має уявлення про сутність і етапи розвитку, становлення соціокультурної дійсності; здатна до полікультурного діалогу в умовах глобалізації).

Окреслені завдання безпосередньо стосуються освіти та виховання, галузей, що перебувають у тісному взаємозвязку із суспільними процесами, нині ж набули провідного значення, перетворившись на чинник потужного розвитку і модернізації суспільства, забезпечення ефективності функціонування не лише економіки, a й політики $\mathrm{i}$ громадянської сфери. Саме на освіту і виховання покладається завдання, виходячи із загальнолюдських цінностей та ідеалів, індивідуального і суспільного світогляду, сформувати особистість, наділену вищеназваними якостями.

Особливе місце в цьому процесі належить середній гуманітарній освіті, оскільки іiі культуротворча функція окрім завершення процесу освоєння людиною культурного поля передбачає i необхідність ініціювання втілення нових тенденцій, які б адекватно відображали основні напрямки розвитку сучасного світу.

Соціальне замовлення, що стоїть нині перед загальноосвітніми закладами, можна визначити в найзагальнішій формі як формування самостійної, ініціативної, духовної особистості, що володіє предметними компетенціями, загальнокультурною компетентністю; має достатній рівень профільної підготовки, необхідної для подальшого оволодіння фахом; відкрита для постійної самоосвіти, готова до новацій і змін. Причому, враховуючи соціокультурну ситуацію, одним із пріоритетних напрямків цієї роботи має стати виховання культури почуттів учня загальноосвітньої школи, як одного зі складників його духовного світу.

Проблема формування культури почуттів є багатоаспектною. У культурологічному плані вона ставилася і послідовно висвітлювалася у розвідках М. Бахтіним, М. Бердясвим, Д. Лихачовим, Г. Сковородою, П. Сорокіним, П. Флоренським, П. Юркевичем та іншими. Ідеї філософів відіграли надзвичайно важливу роль у розробленні методологічних засад формування духовної культури особистості і можуть слугувати теоретичними засадами для розроблення концепції виховання культури почуттів учнів основної школи.

У визначенні закономірностей формування чуттєвої культури ми спиралися на фундаментальні дослідження про виникнення та сутність емоцій (П. Анохін, В. Вундт, У. Джемс, К. Платонов, П. Симонов, П. Якобсон та інші); механізми емоційної регуляції діяльності (О. Запорожець, О. Тихомиров та інші); єдність емоційного та інтелектуального (Л. Божович, Л. Виготський, В. М'ясищев, С. Рубінштейн та інші); зв'язок мотивації та емоцій (В. Асєєв, В. Вілюнас, О. Леонтьєв та інші); форми, засоби, шляхи формування культури емоцій та почуттів (Ш. Амонашвілі, О. Макаренко, В. Сухомлинський, А. Харчев, В. Шаталов, С. Шацький та інші); характерні особливості вияву емоцій в галузі художньої творчості і сприйняття мистецтва (М. Каган, Е. Квятковський, Л. Коваль, С. Раппопорт, Б. Тєплов та інші).

Узагальнення поглядів дослідників дозволяє зробити висновок, що культура почуттів це здатність «чуттєвого резонансу», емоційної саморегуляції, вміння сприймати красу і радіти ӥй, насолоджуватися художніми явищами та подіями. Культура почуттів інтегрує не лише загальну сенсорну розвиненість, а й здатність особистості до переживання i співпереживання. Цілісна природа чуттєвої культури об’єктивує сприйняття людиною навколишнього світу не тільки розумом, але й серцем. Доречним є використання термінів «етика» й «естетика» задля визначення ступенем «олюднення» почуттів.

Висока почуттєва культура за своєю сутністю не стає здобутком особистості. Вона формується і збагачується в результаті співпереживань, що виникають у спілкуванні індивіда 3 іншими людьми, під час сприйняття творів мистецтва, під впливом засобів масової інформації, власних художніх поглядів та смаків, самостійної художньої творчості 
й матеріалізації художньої свідомості через естетику побуту тощо. Окрім перерахованих чинників, зростання рівня чуттєвої культури учнів основної школи забезпечується також раціонально організованою системою навчально-виховного процесу і позанавчальної діяльності учнів.

Безумовно, цілеспрямована робота 3 формування культури почуттів в учнів основної школи потребує систематичності, що сприятиме в подальшому гармонійному вияву таких аспектів культури, як: уміння висловити співчуття, зрозуміти настрій іншої людини і налагодити безконфліктні міжособистісні контакти.

Слід, однак, визнати, що виховання багатства і витонченості почуттів за певною кількістю моментів є більш складним, ніж формування і збагачення інтелекту, оскільки в емоційній сфері найтісніше взаємопов'язано біологічне, психологічне і соціальне. Удосконалення почуттів означає особистісний розвиток їх власника: зміниться ставлення особистості до певного явища - почуття стануть більш яскравими й усвідомленими. Такий розвиток має такі напрямки реалізації:

1) напрямок, пов'язаний із включенням до сфери емоційних переживань людини нових об'єктів і подій;

2) шляхом підвищення рівня свідомого вольового управління особистостістю власними почуттями;

3) насичення внутрішньої структури особистості більш високими цінностями і нормами.

У тісному взаємозв'язку з внутрішнім світом перебуває усвідомлення інтеріоризованих цінностей на рівні «емоційного інтелекту», високий рівень сформованості якого передбачає «емоційну грамотність» особистості і містить такі здібності: 1) розпізнавання власних емоцій; 2) оволодіння емоціями; 3) самомотивація; 4) розуміння емоцій інших людей.

Складність виховання чуттєвої культури полягає також у визначенні дидктичних підходів до розглядуваних процесів, що передбачають належне спрямування почуттєвої сфери людини, оскільки «почуттю наказувати не можна» (К. Станіславський) [9, с. 84], тому що воно не виникає довольно чи за замовленням, почуття можна тільки побічно регулювати за посередництвом діяльності, у якій воно виявляється і формується (С. Рубинштейн) [5, с. 164]. До почуття треба підвести, створивши психологічну ситуацію, яка надає змогу виникнути емоційному ставленню людини до певного кола явищ i пережити певне емоційне ставлення.

Отже, формування чуттєвої культури в учнів основної школи у процесі вивчення художньої літератури корелює із рівнем сформованості художнього смаку, порогу естетичної чутливості до мистецтва.

Застосування принципу систематичності в формуванні чуттєвої культури учнів основної школи дозволяє приділити рівноцінну увагу всім ii компонентам: сенсорному розвитку, емоційності, емпатії, емоційному самоконтролю та регуляції, збагаченню чуттєвого досвіду. Тільки забезпечення виконання цієї вимоги дозволить сформувати емоційно культурного учня, який відрізнятиметься пізнавальною активністю, зростанням духовних потреб, широтою естетичних інтересів, виявом гуманістичного початку у поведінці, потребою емоційного насичення та творчої діяльності.

Усі ці якості розвиваються в процесі цілеспрямованого залучення людини до художніх цінностей, збагачення іiі духовно-творчого потенціалу. Шляхи розв'язання окресленої проблеми різноманітні, але художнє виховання, на нашу думку, відіграє особливу роль у формуванні чуттєвої культури, оскільки вона отримує найповніше втілення саме в художній культурі (сукупності усіх мистецтв). Ті переживання, емоції, почуття, естетична насолода, які виникають під час сприйняття людиною мистецтва, формують ії почуттєве ставлення до світу. Художнє виховання, як суттєвий елемент системи загального виховання, надає процесу формування особистості закінченості, насичуючи його сутнісно людським змістом. 
У процесі дослідження ми звернули увагу, що досить часто художнє виховання педагогами, методистами ототожнюється з естетичним. Однак ці поняття необхідно чітко розмежовувати. За основу нами було прийнято концепція С. Шацького, В. Шацької, М. Кагана та інших, які відокремлювали естетичне і художнє виховання. Так, наприклад, В. Шацька ставить перед естетичним вихованням мету, що визначає естетичне виховання як таке, що слугує формуванню здатності активного естетичного ставлення учнів до творів мистецтва, а також стимулює посильну участь у створенні прекрасного в мистецтві, праці, у творчості за законами краси [8, с. 14]. Аналізуючи концептуальну позицію науковця, робимо висновок, що автор важливе місце в естетичному вихованні відводить мистецтву. Водночас мистецтво становить складник естетичної культури, рівноцінно як художнє виховання становить складник естетичного, частина суттєва, вагома, протее така, що охоплює тільки одну сферу людської діяльності. Безпосередній зв'язок із залученням особистості до мистецтва має, на думку С. Шацького, саме художнє виховання, як процес «цілеспрямованого впливу на особистість засобами мистецтва, завдяки чому у вихованців формуються художні почуття і смак, любов до мистецтва, вміння розуміти його, насолоджуватися ним і здатність по можливості діяти в мистецтві» [8, с. 61].

Естетичне виховання є набагато ширшим поняттям, оскільки містить у своєму складі як художню творчість, так і естетику побуту, поведінки, праці, відносин. Воно формує особистість усіма естетично значимими предметами та явищами, в тому числі і мистецтвом, як його наймогутнішим засобом, але не лише для мистецтва, а для іï активної естетичної життєдіяльності. Цікавою для нашого дослідження щодо взаємозв'язку естетичного та художнього є думка А. Лосєва: «Естетичне є те, що повинно здійснитись у вигляді мистецтва. Художнє - це здійснене естетичне» [9, с. 133]. Водночас українська естетична школа (В. Іванов, В. Мазепа, А. Канарський та інші) розуміють діалектику естетичного як теорію чуттєвого пізнання, чуттєвої культури.

Художнє виховання учнів основної школи трактується нами як процес ії цілеспрямованого залучення до мистецтва та формування 3 його допомогою чуттєвої культури учнів, розширення їхнього художнього світогляду і стимулювання потреби збагачувати світ прекрасного. Воно сприяє удосконаленню художньо-образного мислення учнів, розвиває їхню художню ерудицію і смак, розширяє палітру естетично-емоційних вражень, розв'язує завдання осмисленого ставлення до мистецтва як до мови.

В. Сухомлинський так інтерпретував розуміння прекрасного: «У дитинстві мої вихованці любили слухати музику квітучого саду і поля гречки, весняних луків та осіннього дощу. Вони відчували, переживали красу навколишнього світу, і це робило їх душі шляхетними. Але якою б прекрасною не була музика природи, це ще не музика. Це літери, за допомогою яких людина може приступати до читання книжки на мові почуттів» [6, с. 63]. В. Сухомлинський справедливо вважав, що такою «книжкою» у вихованні чуттєвої культури, джерелом пізнання світу почуттів повинно стати мистецтво. Навчившись помічати, розуміти й цінувати красу мистецьких шедеврів, молоде покоління перенесе почуття прекрасного та шанобливе ставлення до краси у власну життєдіяльність. Такий вплив художнього виховання у процесі вивчення художньої літератури дозволяє стверджувати про його надзвичайне місце і роль в духовному відтворенні людини.

Отже, визначаємо потужні людинотворчі можливості мистецтва у формуванні особистості, водночас, саме воно 3 притаманним йому впливом на свідомість i підсвідомість, на інтелектуальну та почуттєву сферу, на моральне і навіть на фізичне здоров’я індивіда, має особливий виховний потенціал. Мистецтво створює переконливу картину досконалого життя, формує гуманістичні принципи поведінки; спілкування з ним дозволяє людині відновити або розвинути природне, закладене в ній багатство духовного світу.

Мистецтву належить важлива місія в онтології виживання людства, оскільки протягом усієї історії свого існування воно робило велику справу гуманізації людського життя, розкривало перед людиною красу навколишнього світу. Корелює із зазначеною позицією 
думка М. Бахтіна, який убачав цінність мистецтва не у відображенні буття, не в його пізнанні, а в естетичному перетворенні світу в новій формі [1, с. 21].

У дослідженнях науковців (А. Леонтьєв, М. Каган) послідовно також висвітлено питання сутності взаємозв'язку мистецтва й культури спілкування. Зокрема, науковці розуміють у цьому сенсі мистецтво як специфічний спосіб людського спілкування. Художній діалог між творцем і слухачем (глядачем) становить особливий тип духовної взаємодії, що стимулює активність особистості, спрямовану на співтворчість. Під час подібного спілкування відбувається органічне передавання від автора певного переживання до того, хто його почуттєво сприймає. Результатом цього процесу $є$ органічний розвиток художньої свідомості реципієнта, причому особливість полягає в тому, що естетичні цінності не приймаються готовими, а виробляються ним самостійно на основі переживань. Специфікою процесу художнього спілкування $є$ те, що людина, яка сприймає мистецький твір, виконує роль «співтворця» автора. Митець володіє певним матеріалом, видозмінюючи його у художній образ та насичуючи почуттями. Глядач (слухач) на основі перероблених в уяві художніх об'єктів будує власний образ.

Для нас питомий науковий i практичний інтерес становлять також дані про стимулюючий вплив мистецтва на здібності особистості, iї загальний розвиток. Експериментально доведеною є залежність навчальної успішності учнів середніх шкіл від рівня розвитку їх емоційної сфери. Мається на увазі, що для вивчення різних наук мозок повинен досягти певного рівня розвитку, що можливе лише за умови регулярних сенсорних впливів. Відповідно, найважливішу роль у формуванні чуттєвої культури відіграє художнє виховання.

Спираючись на чуттєву сферу людини, мистецтво поступово привчає їі сприймати зміст твору через форму: читати в літературі, чути в музиці, бачити в образотворчому мистецтві. Саме таке не просто сприйняття, а активне сприйняття мистецьких творів $\epsilon$ початком духовної практики людини [2, с. 125]. Тренуючи гнучкість почуттів, мистецтво $€$ одним з найдієвіших засобів впливу на духовний розвиток особистості, допомагає ій знайти повноту емоційних зв'язків із довкіллям. Продовжуючи наведені міркування, В.Зінченко слушно зауважує, що, відкриваючи і пізнаючи світ мистецтва, індивід формує своєрідну «партитуру почуттів», задовільняє потребу свободи і творчості, забезпечує самореалізацію власної індивідуальності, самовиховання душі і самовдосконалення [2, c. 131].

Отже, за умови поступового введення учнів основної школи у процесі вивчення художньої літератури до світу літературного мистецтва, створюючи навколо них художньо-естетичне середовище, ми забезпечуємо процес «олюднення» їхніх почуттів, закладаємо міцний підмурок їхньої загальної культури й духовності.

Виходячи з викладеного вище, визначимо такі завдання художнього виховання у процесі формування чуттєвої культури учнів основної школи:

1. Набуття теоретичних знань i формування практичних умінь у процесі залучення учнів основної школи до цінностей літературного мистецтва шляхом нагромадження необхідного запасу знань та вражень (звук, колір, пластика тощо у художньому творі; система зображально-виражальних засобів), без яких не може виникнути цікавість до мистецтва, а згодом і радість від процесу спілкування з ним.

На основі удосконалення художнього сприйняття та створення багажу необхідних знань в учнів основної школи формуються такі соціально-психологічні якості, що забезпечують їм можливість емоційно переживати та оцінювати мистецькі твори, насолоджуватися ними. Особливу увагу на цьому етапі слід приділити розвитку емоційної пам'яті учнів у процесі вивчення конкретного художнього твору, тому що саме вона лежить в основі художнього досвіду, який, в свою чергу, позитивно впливає на пробудження, збагачення творчої фантазії особистості, створює умови для iї духовного розвитку $[3$, с. $78 ; 9$, с. $236 ; 7$, с. $154 ; 10$, с. 125$]$. Зазначимо, що художній досвід не $є$ чимось сталим, водночас характеризується динамічними змінами; формується й 
удосконалюється під впливом мистецьких смаків та естетичних почуттів особистості, iї оцінок та ідеалів. Від його багатства безпосередньо залежить розвинутість культурних потреб та інтересів особистості в галузі мистецтва, рівень досконалості їі «мистецької свідомості».

На другому етапі художнього виховання здатність учнів основної школи до глибокого переживання естетичних почуттів має поєднатися з їхніми вміннями висловлювати власне естетичне судження щодо мистецьких творів, давати естетичну оцінку явищам мистецтва. Така оцінка визначається як заснована на визначених естетичних принципах, глибокому розумінні сутності естетичного, що припускає аналіз, можливість доказу, аргументації.

Отже, учні основної школи мають навчитися самостійно, 3 урахуванням вікових можливостей, критично оцінювати будь-який мистецький твір i аргументувати власні враження й емоційний стан. Зрозуміло, що набагато складніше давати обгрунтовану оцінку, ніж просто висловлювати свій суб'єктивний погляд - подобається чи ні. Водночас, оцінка твору літератруного мистецтва має торкатися не лише змісту, а й форми та історії його створення. Бажано, щоб під час літератруного аналізу художнього твору учні основної школи намагалися визначити своєрідність розкриття художником певної теми, відчули його стиль $\mathrm{i}$ творчий почерк, особливості використаних виразних засобів. Важливо також формувати в них здатність сприймати і оцінювати окремі складники художнього цілого: вміння знаходити у розвитку художнього образу опорні, вузлові пункти дозволить студентам краще зрозуміти поставлені митцем проблеми, твір мистецтва розкриватиметься перед ними як естетична цінність, як світ краси.

Вивчаючи окреслену проблему, М.Коляденко пропонує розглядати процес ознайомлення 3 мистецьким твором через призму «синтетичних художніх образів», сформованих під час сприйняття. Іншими словами, прагнути до розуміння не тексту, а підтексту. Тобто, аналіз будь-якого художнього явища має рухатись від сприйняття, розуміння окремої його деталі до охоплення цілісного загального художньо-естетичного задуму з поступовим проникненням у більш глибокі його надра [9, с. 112]. Такий підхід забезпечить формування в учнів основної школи чуттєвого ставлення до світу як основи духовного сенсу людського життя, дозволить у процесі художньо-творчої діяльності через чуттєві художні образи як окремі складники єдиного цілого зробити установку на духовний підтекст мистецтва [3, с. $57 ; 4$, с. 69].

Ці завдання можуть бути розв'язаними лише за умови тісної інтеграції в процесі художнього виховання різних видів мистецтва. Якщо, наприклад, учитель української літератури аналізуватиме музичні твори в тісному взаємозв'язку 3 літературою та 3 образотворчим мистецтвом, то розуміння специфіки кожного 3 цих мистецтв допоможе студентам не лише поглибити відчуття їх особливостей і своєрідності, а й сприятиме формуванню цілісного уявлення про мистецтво як образну форму відображення дійсності. Пропонований підхід допоможе учням основної школи у процесі вивчення художньої літератури усвідомити, що різні види мистецтва не тільки не відокремлені одне від одного, а, навпаки, мають тісний взаємозв'язок, і знання одного з них допомагає глибшому сприйманню й розумінню інших видів мистецтва. Створений у свідомості молодої людини багатогранний художній образ отримає завдяки цьому нову якість і за змістом, і за формою, розширить можливості свого виховного впливу на індивіда.

Отже, комплексний підхід до процесу художнього розвитку учнів основної школи у процесі вивчення художньої літератури, на нашу думку, забезпечить не лише кореляцію у розумінні кількох самостійних творів, але перш за все гармонійний розвиток когнітивного, емоційного та праксеологічного складників художньої культури учня основної школи, поєднання різних форм його мистецької діяльності (за умови її перебігу на основі теоретичного мислення, спрямованого на усвідомлення суті мистецького явища, відкриття його внутрішніх і зовнішніх зв'язків).

Перспективами подальших досліджень $є$ розкриття взаємозв'язку між рівнями сформованості когнітивного, емоційного та праксеологічного складників художньої 
культури учня основної школи і рівнем сформованості читецьких компетенцій у процесі вивчення художньої літератури.

\title{
Література
}

1. Бахтин М. М. Вопросы литературы и эстетики / М. М. Бахтин. - М. : Художественная литература, 1975. - 504 с. 2. Зинченко В. П. Размышления о душе и ее воспитании (час души) / В. П. Зинченко // Вопросы философии. - 2002. - №2. - С. 119-136. 3. Лихачев Д. Б. Теория эстетического воспитания школьников / Б. Б. Лихачов. - М., 1985. - 176 с. 4. Подольська Є. А. Культурологія : [навч. посіб.] / Подольська Є. А., Лихвар В. Д., Іванова К. А. - К. : Центр навчальної літератури, 2003. - 288 с. 5. Рубинштейн С. Л. Основы общей психологии : в 2 т. / С. Л. Рубинштейн ; АПН СССР. - М. : Педагогика, 1989. - Т. 2. - 1989. - 323 с. 6. Сухомлинський В. О. Вибрані твори : в 5-ти т. Серце віддію дітям. Народження громадянина. Листи до сина / В. О. Сухомлинський. - К. : Радянська школа, 1977. - Т.3. - 670 с. 7. Флоренская Т. А. Проблема психологии катарсиса как преобразования личности / Т. А. Флоренская // Психологические механизмы регуляции социального поведения. - М. : Наука, 1979. - С.151-174. 8. Шацкий С. Т. Избранные педагогические сочинения : в 2 т./ С. Т. Шацкий. - М. : Педагогика, 1980. - Т.2. - 416 с. 9. Эстетическое воспитание молодежи средствами искусства / под ред. Бутенко В. Г. - М., 1991. 242 с. 10. Якобсон П. М. Психология чувств / П. М. Якобсон / АПН РСФСР, Ин- т психологии. М. : Изд- во АПН РСФСР, 1956. - 237 с.

УДК 908(07):5

\author{
А. А. Самолюк, \\ аспірант, \\ ДВНЗ «Переяслав-Хмельнииький державний \\ педагогічний університет імені Григорія Сковороди»
}

\section{ТЕНДЕНЦІЇ РОЗВИТКУ КРАЕЗНАВЧОЇ ОСВІТИ У ЗМІСТІ МЕТОДИЧНИХ РЕКОМЕНДАЦІЙ ДЛЯ ВЧИТЕЛІВ ЗОШ ІЗ ФОРМУВАННЯ ТВОРЧОЇ АКТИВНОСТІ УЧНІВ ОСНОВНОЇ ШКОЛИ У ПРОЦЕСІ ТУРИСТСЬКО-КРАЄЗНАВЧОЇ РОБОТИ}

Самалюк А. А. Тенденції розвитку краєзнавчої освіти у змісті методичних рекомендацій для вчителів зош із формування творчої активності учнів основної школи у процесі туристськокраєзнавчої роботи.

У статті розкрито тенденції розвитку краєзнавчої освіти як складника природознавчої освіти. Доведено, що оволодіння краєзнавчим матеріалом сприяє активізації творчого потенціалу в учнів основної школи у процесі туристсько-краєзнавчої роботи.

Ключові слова: краєзнавча освіта, учні основної школи, творча активність, творчий потенціал, туристсько-краєзнавча освіта.

Самалюк А. А. Тенденции развития краеведческого образования в содержании методических рекомендаций для учителей ОСШ по формированию творческой активности учащихся основной школы в процессе туристическо-краеведческой работы.

В статье раскрыты тенденции развития краеведческого образования как составляющей природоведческого образования. Доказано, что овладение краеведческим материалом способствует активизации творческого потенциала у учеников основной школы в процесс се туристическо-краеведческой работы.

Ключевые слова: краеведческое образование, ученики основной школы, творческая активность, творческий потенциал, туристически-краеведческое образование.

Samalyuk A. A. Trends in local history education in the content of methodological recommendations for teachers of secondary schools for the purposes of formation of creative activity of basic school students in the tourism and local history work.

The article reveals trends in local history education as a component of the Natural History of Education. Proved that mastering local history materialom sposobostvuet enhance creativity among elementary school students in the process se-tourist local history work.

Key words: local history education, primary school students, creativity, creative potentsial, turichticheski-regional studies education. 